\title{
Review of Estimating Trophic Relationships by Quantitative Fatty Acid Signature Analysis
}

\author{
Junbo Zhang ${ }^{1,2,3,4, *}$, Chonglan Ren ${ }^{1, \dagger}{ }^{\dagger}$ Hu Zhang ${ }^{5}$, Fang Yin ${ }^{6}$, Shuo Zhang ${ }^{1, *}$, Rong Wan ${ }^{1,4, *}$ \\ and Daisuke Kitazawa ${ }^{7}$ (i) \\ 1 College of Marine Sciences, Shanghai Ocean University, Shanghai 201306, China; renchonglan_cz88@163.com \\ 2 National Engineering Research Center for Oceanic Fisheries, Shanghai 201306, China \\ 3 Key Laboratory of Sustainable Exploitation of Oceanic Fisheries Resources, Ministry of Education, \\ Shanghai 201306, China \\ 4 Key Laboratory of Oceanic Fisheries Exploration, Ministry of Agriculture and Rural Affairs, \\ Shanghai 201306, China \\ 5 Laboratory of Resource and Environment, Maine Fisheries Research Institution of Jiangsu, \\ Nantong 226000, China; ahu80@163.com \\ 6 College of Ocean Science and Engineering, Shanghai Maritime University, Shanghai 201306, China; \\ fangyin@shmtu.edu.cn \\ 7 Institute of Industrial Science, the University of Tokyo, 5-1-5 Kashiwanoha, Kashiwa-shi, Chiba \\ 277-8574, Japan; dkita@iis.u-tokyo.ac.jp \\ * Correspondence: zhangjunbo1985@gmail.com (J.Z.); s-zhang@shou.edu.cn (S.Z.); rwan@shou.edu.cn (R.W.) \\ + The second author contributed equally to this work and is the co-first author.
}

Received: 26 October 2020; Accepted: 14 December 2020; Published: 18 December 2020

\begin{abstract}
The dynamic predator-prey relations in the food web are vital for understanding the function and structure of ecosystems. Dietary estimation is a research hotspot of quantitative ecology, providing key insights into predator-prey relationships. One of the most promising approaches is quantitative fatty acid signature analysis (QFASA), which is the first generation of statistical tools to estimate the quantitative trophic predator-prey relationships by comparing the fatty acid (FA) signatures among predators and their prey. QFASA has been continuously widely applied, refined and extended since its introduction. This article reviewed the research progress of QFASA from development and application. QFASA reflects the long-term diet of predator, and provides the quantitative dietary composition of predator, but it is sensitive to the metabolism of predator. The calibration coefficients (CCs) and the FA subset are two crucial parameters to explain the metabolism of predators, but the incorrect construction or improper use of CCs and the FA subset may cause bias in dietary estimation. Further study and refinement of the QFASA approach is needed to identify recommendations for which CCs and subsets of FA work best for different taxa and systems.
\end{abstract}

Keywords: quantitative fatty acid signature analysis; aquatic food webs; dietary estimation

\section{Introduction}

To understand the structure and function of aquatic ecosystems and realize the trophic predator-prey relationships, it is necessary to obtain accurate dietary composition of predators. In aquatic ecosystems, the impracticality and limitations of direct observation method of feeding have prompted the development of indirect dietary estimation methods [1], such as the stomach content analysis [2], the stable isotopes (SI) analysis [3] and fatty acid (FA) analysis [4]. As one of the promising methods, FA analysis is based on the fact that specific FA can only be produced by certain primary producers (usually algae and bacteria), and higher trophic levels cannot synthesize by themselves; therefore, it can be used to track food sources. Fatty acids (FAs) have been widely applied in qualitative 
studies for analyzing the trophic predator-prey relationships. Then, Iverson et al. [5] developed a new method named quantitative fatty acid signature analysis (QFASA), which was the first time FAs have been used to quantitatively estimate the diet of predators.

The QFASA model has been continuously refined and extended, though it has been extensively applied in diet estimation. This article reviews the development of QFASA in the dietary estimation of aquatic species, and discusses the application scope of QFASA based on its merits and demerits. The aim of this paper is to provide a reference when applying QFASA to the quantitative evaluation of trophic relationship in marine ecosystem.

\section{Fundamental Requirements of QFASA}

QFASA is related to the characteristics of FAs. The differences in FA biosynthesis among species make it possible to identify the original source of certain FA. Firstly, FAs in prey are transferred, largely unaltered or at least in a predictable manner, to lipid storage sites (i.e., adipose tissue) of their predators, and reflect the long-term diet. Secondly, FAs derived from food are called dietary FAs, some of which can only be produced by specific species (such as algae and bacteria), and are essential for the survival of organisms, also called essential FAs [6]. Thirdly, in contrast to primary producers, other species usually can only produce some simple FAs (e.g., 14:0, 16:0, and 18:0 saturated FA; 14:1n-5, 16:1n-7, and 18:1n-9 monounsaturated FA) [7].

To understand the QFASA model, it is necessary to understand the terms of FA signature and calibration coefficient (CC).

The first issue is FA signature. According to Iverson et al. [5], the quantitative distribution of all FAs obtained in samples (prey or predators) is called FA signature. Each prey species has a unique pattern of FA signature due to the difference of life history and dietary habits [8]. As these signatures are conserved through the food chain, they can act as indicators of dietary composition [8].

The second issue is CC, which is a coefficient to calibrate the lipid metabolism process in the fat tissue of the predator [5]. Due to the biosynthesis, mobilization, modification and deposition of FAs, the FA signature of the predator is not completely consistent with its prey. Calibration coefficients (CCs) were determined previously from feeding experiments of individuals on a given long-term diet, with the assumption that after such long-term feeding, the adipose tissue stored in the predator will be similar to the given diet [5,9-11]. Then it can be calculated as the discrepancy or ratio, between adipose tissue and diet levels of each FA [5], as follows:

$$
\mathrm{CC}=\text { Predator/Prey }
$$

Fundamental requirements for the application of QFASA are as follows: (i) a predator tissue properly sampled, stored, extracted and analyzed for FA signature; (ii) an appropriate sampling analysis of FA signature of potential prey species for a predator; (iii) the lipid metabolism and deposition of predator estimated, usually through captive feeding experiments; (iv) a quantitative model to minimize the distance of FA signatures between a predator and its prey [5]. More detailed information about the initial QFASA model can be found in the study of Iverson et al. [5], and further discussion of the model can be found in the article by Budge et al. [12].

QFASA is the first generation of statistical tools to evaluate the quantitative trophic predator-prey relationships by comparing the FA signatures among predators and their prey [5]. Taking into account the metabolism of the predator, the technique aims to find the combination of prey, based on their FA signatures, which yields a combined FA signature similar to that of the predator [5]. QFASA is developed based on two main hypotheses: the representative prey signature database contains all potential prey taxa and CCs are known and accurate [13].

QFASA can be used for individuals as well as food webs. Figure 1 is revised from Magnone et al. [14], who applied QFASA to generate a food web model in the aquatic environment to find out the trophic 
relationships among the species. The arrows point from all predators to their prey and the percentage represents the proportion of prey in the diet of predator.

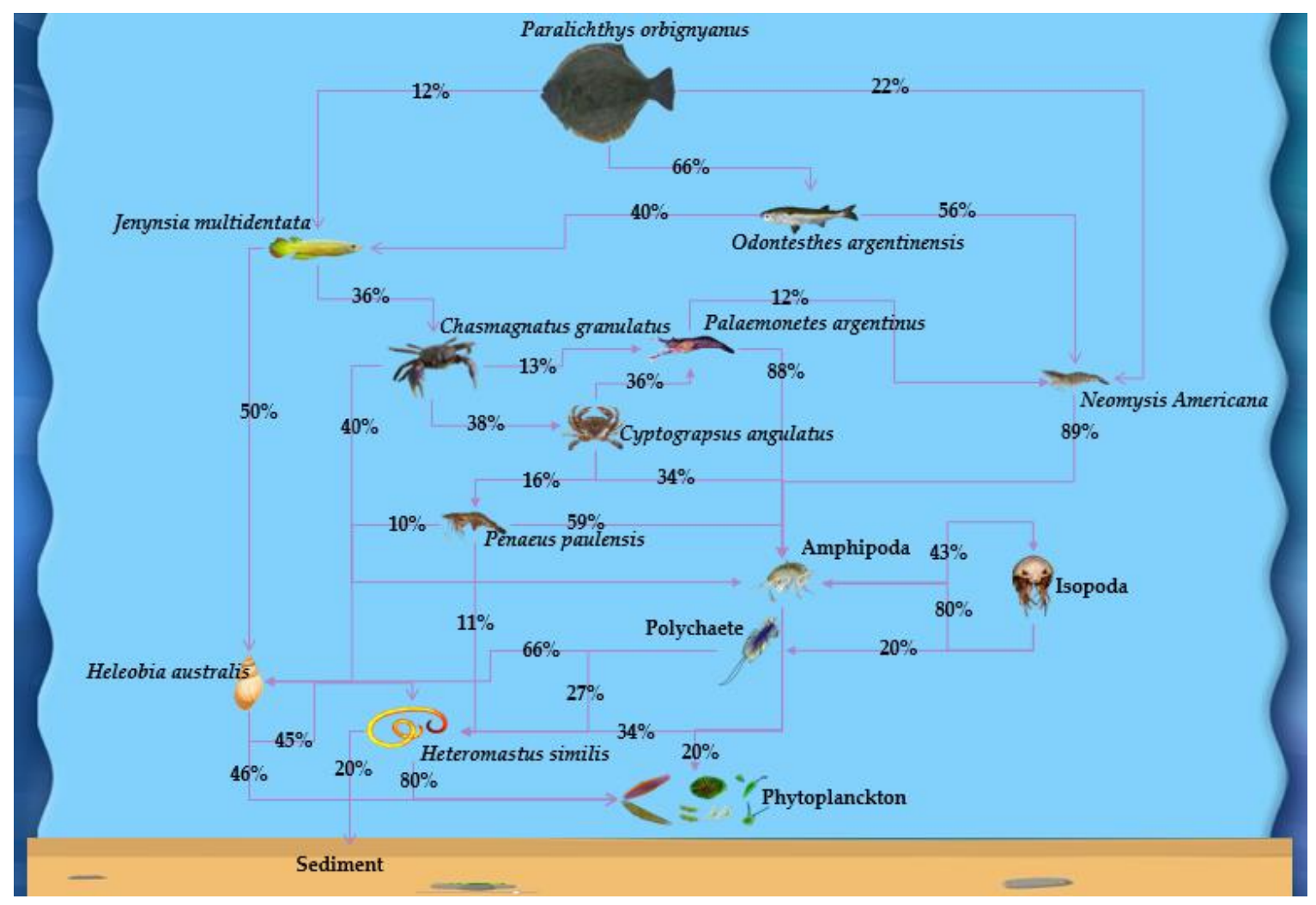

Figure 1. Quantitative trophic predator-prey relationships. (Revised from Magnone et al. [14]).

\section{Ecological Modeling}

The dietary assessment of each predator is acquired from the weighted combination of its prey's FA signatures, and then the weighted coefficient with the lowest statistical distance from the predator's FA signature is selected. This is achieved by minimizing the statistical distance between the prey's FA signatures weighted combination and predator's FA signature. The flow chart of QFASA application is shown in Figure 2 and the ecological modeling is as follows [5]:

The QFASA model considering the vectors of prey $(x)$ and predator $(y)$, originally developed by Iverson et al. [5], combined with the Kullback-Liebler $(K L)$ distance, can be expressed as:

$$
\begin{gathered}
\hat{y}=\sum_{k} p_{k} \hat{x}_{k} \\
K L=\sum_{j}\left(y_{j}-\hat{y}_{j}\right) \log \left(\frac{y_{j}}{\hat{y}_{j}}\right)
\end{gathered}
$$

where $\hat{y}$ is weighted sum of the FA of the prey, $\hat{x}_{k}$ is a vector of the prey species $k, \hat{x}_{k j}$ represents the mean of each FA $j$ of the prey species $k, p_{k}$ is a weight coefficient corresponding to the evaluated proportion of the $k$ in the diet of predator, $y_{j}$ represents the proportion of each FA $j$ of the predator, and $\hat{y}_{j}$ represents the estimated value of each FA $j$ of the predator. 
The aim of the model is to select the $p_{k}$ that makes the estimated value $\hat{y}$ as near as possible to the true value $y$. Because the $p_{k}$ values are greater than or equal to zero and the sum of $p_{k}$ values is 1 , the evaluation can be transformed into a constrained optimization problem [14,15],

$$
\begin{gathered}
\min K L=\sum_{j}\left(y_{j}-\hat{y}_{j}\right) \log \left(\frac{y_{j}}{\hat{y}_{j}}\right) \\
\sum_{k} p_{k}=1, p_{k} \geq 0
\end{gathered}
$$

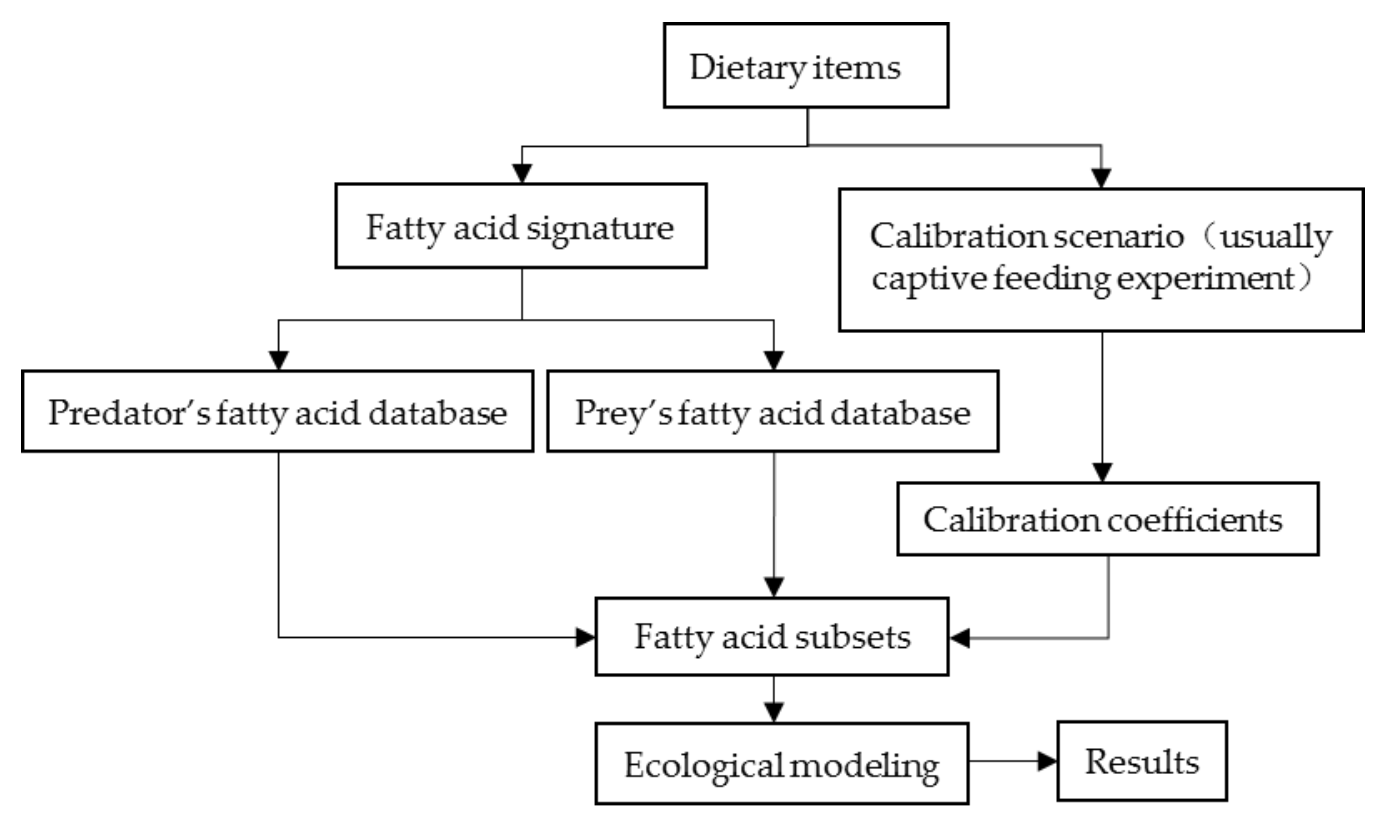

Figure 2. The application flow of quantitative fatty acid signature analysis (QFASA).

\section{The Research Progress of QFASA}

\subsection{The Improvement of QFASA}

The improvement of the QFASA model mainly includes the testing of the method in new taxa, selection and refinement of prey library, calculation of CC, selection of the FA subsets, and optimization of the statistical model.

\subsubsection{The Testing of the Method in New Taxa}

At first, QFASA was intended for estimating the dietary composition of marine mammals [5]. Subsequently, it has been used in multiple predators in various ecosystems, including marine mammals [16-19], seabirds [9-11,20], and fishes [14,15,21-23]. The development history of QFASA is shown in Figure 3, and each node (indicated by a circle) in the figure represents the first application to this species type.

In previous research, as shown in Figure 3, Iverson et al. [5] developed QFASA to estimate the dietary composition of Halichoerus. grypus and Phoca. groenlandica, and concluded that QFASA can be applicable to various predators and ecosystems; Iverson et al. [9] also applied QFASA to seabirds for the first time, and estimated the diets of Uria. aalge and red-legged kittiwakes; Wang et al. [10] estimated the dietary composition of threatened species (Somateria. Wscheri and Polysticta. stelleri) by QFASA, and inferred that QFASA can be used with other wild eiders or birds, and can estimate their diet composition at different life stages; Budge et al. [21] applied QFASA to marine fish for the first time and studied the diets of Atlantic salmon (Salmo. salar) (Figure 3); in addition, Magnone et al. [14] used 
QFASA to generate a food web model in the aquatic environment to find out the trophic relationships among the species, and this was the first time that QFASA has been used to construct food web.

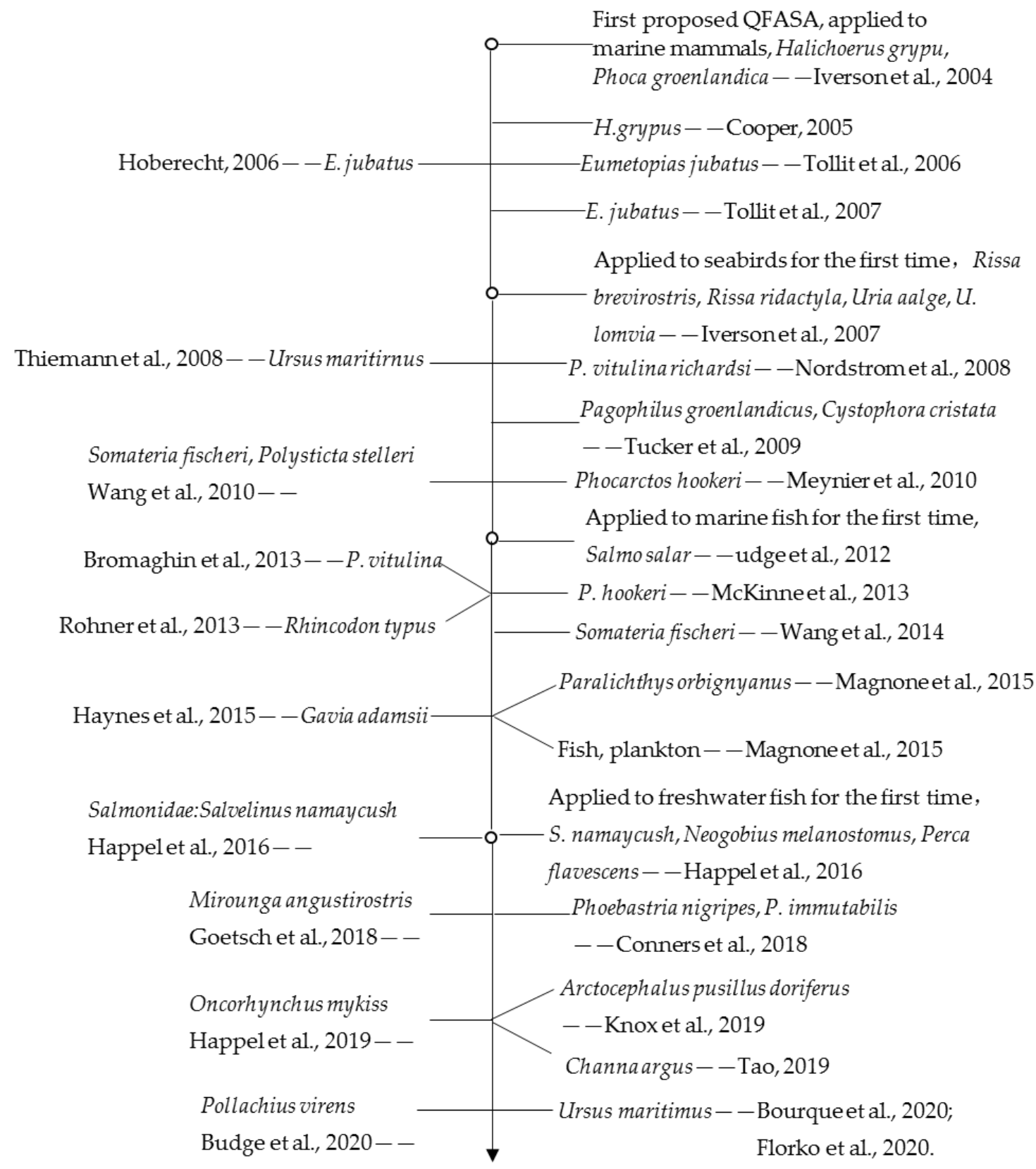

Figure 3. Development history of QFASA's dietary items.

In recent studies, Goetsch et al. [19] estimated the dietary composition of Mirounga angustirostris across five years; Conners et al. [20] studied the dietary composition of two albatross species through QFASA, which was beneficial to understand their fishery exploitation; Knox et al. [24] also evaluated the dietary composition of Arctocephalus pusillus doriferus by QFASA. It is obviously shown that the predator taxa of QFASA are dominated by marine species, mainly including marine mammals, seabirds, and fishes. In addition, as shown in Figure 3, there have been several studies focused on the diet of freshwater fishes in recent years [22,23,25,26], such as Salvelinus namaycush by Happel et al. [22]. 


\subsubsection{The Selection and Refinement of Prey Library}

A pre-condition of QFASA is a prey library which contains the potential prey species of predator [5], and each prey species has a unique FA signature. QFASA uses the average value of each prey to evaluate its contribution to the signature of the predator. However, wild animals consume individuals of different species rather than homogeneous species [5]. Although it is likely to identify the species in the ecosystem by its FA signature, there may be considerable differences within species, such as the same species but different ages or sizes. For instance, studies have found that the lipid content of sprat changes drastically with age and size [27]. Moreover, Magnone et al. [14] treated the young and adult Paralichthys orbignyanus as two types, and found that the adult P. orbignyanus was the top predator in the ecosystem studied while the young P. orbignyanus was prey of other species, and the dietary composition was different from each other. Therefore, species subgroups can be introduced into the QFASA model to provide extra details of diet. It is recommended that the age and size of prey should be taken into account when applying the QFASA model, and species with drastic changes in lipid content could be regarded as two types.

Besides, it is necessary to ensure that the quantity of FAs used in model is no less than the amount of potential prey in the database [19], otherwise, the estimated value of diet will be non-unique $[18,28]$. Three solutions are used to solve this problem based on previous studies. Firstly, multiple prey types with FAs alike could be assembled as a single type before applying QFASA $[18,29,30]$. Secondly, a post hoc method, assessing the diet of each prey as a unique type, is then pooling the estimated values of those prey into their respective communities [17]. Thirdly, Goetsch et al. [19] proposed an ad hoc approach (Drop Core Prey Analysis) to recognize the prey that did not contribute much to the diet and eliminate them from the model. In general, the first method may cause the mean FAs of the mixed prey species to be dissimilar to the practical prey, and the second method cannot ensure if the estimated value of the mixed diet is unique [19]. In contrast, the third method could avoid the deficiencies of the two methods above.

\subsubsection{The Calculation of CCs}

In addition to a detailed knowledge of the FA signatures of all potential prey, an understanding of the biochemistry and metabolism of FA within predators is essential to use this method accurately. At present, QFASA has two crucial parameters to explain the metabolism of predators: the set of CC for individual FA and the subset of FA used in modeling diets [5].

The first issue is CC, which accounts for the lipid metabolism of the predator. CCs were determined previously from captive feeding experiments. Although the CCs for a variety of birds, mammals, and fishes $[11,15]$ have been determined, which is shown in Table 1 , feeding experiments of most predators have not been conducted. In that condition, the developed CC of a surrogate species is normally used based on the evolutionary and ecological similarities. For instance, Thiemann et al. [16] used the CC of Mustela vison to replace the CC of polar bears; Meynier et al. [17] compared five sets of CC calculated by Iverson et al. [5] and Tollit et al. [31] then chose available CC that can be used for the application of QFASA on Phocarctos hookeri; Haynes et al. [30] used three CCs obtained by Iverson et al. [9] and Wang et al. [10] to replace the CC of Gavia adamsii by feeding trials.

Some studies have shown that diet estimation is very sensitive to the selection of $\mathrm{CC}$, and the errors in CC would cause bias in dietary estimation [13,30]. Whereas, the factors such as feeding time and the type of food fed may affect the adaptability of the obtained CC in the study of wild predators [21,32] and the accuracy of CC in dietary estimation of wild animals cannot be verified. These issues have caused considerable criticism, and some recent studies emphasized and pointed out that using QFASA without CC is also sufficiently robust [15,21,22,32,33]. For instance, Budge et al. [21] used five calibration scenarios (four sets of $C C$ were determined by captive feeding experiments, and the fifth calibration scenario was modeled without (C) to verify the application of QFASA in fish. They found a tendency to overestimate the dietary components used as prey for CC calculations, which indicates that applying QFASA without CCs to quantitatively estimate the dietary components 
and the trophic relationships in aquatic food web might be sufficiently robust. Magnone et al. [14] generated a food web model in the aquatic environment without CCs, found the results were similar to the previous knowledge; Happel et al. [22] illustrated that the prey used to make CCs can affect QFASA outputs and that perhaps ignoring CCs was a better method. Moreover, in a latest research, Bromaghin et al. [33] proposed a model that can simultaneously estimate CC and dietary composition on the basis of FA signature samples of predator and its preys alone. In summary, the application of CC depends on the species and system being studied, and the diet estimation of fish without CC is sufficiently robust, and for other taxa which are difficult to conduct captive feeding trials, it is recommended to refer to the model proposed by Bromaghin et al. [33].

Table 1. Captive feeding trials to improve the precision of quantitative fatty acid signature analysis (QFASA).

\begin{tabular}{|c|c|c|}
\hline Species & Captive Feeding Trials & References \\
\hline $\begin{array}{l}\text { Halichoerus grypus, } \\
\text { Phoca groenlandica }\end{array}$ & $\begin{array}{l}\text { The CCs were originated from seals that fed herring for } \\
\text { five months. }\end{array}$ & [5] \\
\hline H. grypus & $\begin{array}{l}\text { The CCs were obtained by replacing the mixed wild } \\
\text { types with a homogeneous test diet via gastric cannula. }\end{array}$ & [8] \\
\hline Eumetopias jubatus & $\begin{array}{l}\text { The CCs were derived from the FA signature of blubber } \\
\text { that has been fed only herring for a long time. }\end{array}$ & [34] \\
\hline E. jubatus & Simulated ephemeral feeding events of E. jubatus. & [35] \\
\hline Uria aalge & $\begin{array}{c}\text { The CCs were obtained from silverside which had been } \\
\text { raised in captivity since birth. }\end{array}$ & [9] \\
\hline E. jubatus & $\begin{array}{c}\text { Three CCs sets derived from constant diet respectively of } \\
\text { Clupea pallasii, Thaleichthys pacificus or the mixture } \\
\text { of them. }\end{array}$ & [31] \\
\hline P. vitulina richardsi & $\begin{array}{l}\text { The CCs were estimated from four seals fed herring. } \\
\text { The female birds were grouped by type and kept in }\end{array}$ & [36] \\
\hline $\begin{array}{l}\text { Somateria fischeri, } \\
\text { Polysticta stelleri }\end{array}$ & $\begin{array}{l}\text { outdoor natural saline habitats respectively, and offered } \\
\text { different proportions for each experimental diet, then } \\
\text { proceed biopsy sampling. }\end{array}$ & [10] \\
\hline Salmo salar & $\begin{array}{c}\text { The changes of CCs with the FA signatures in the diet } \\
\text { were investigated by feeding salmon with diet of } \\
\text { different FA compositions. }\end{array}$ & [21] \\
\hline S. fischeri & Developed CCs for individual FA for eggs. & [11] \\
\hline Paralichthys orbignyanus & $\begin{array}{l}\text { The CCs used for P. orbignyanus was obtained through } \\
\text { the controlled feeding experiments of feeding on } \\
\text { silverside and menhaden for } 20 \text { weeks. }\end{array}$ & [15] \\
\hline $\begin{array}{l}\text { Salmonidae: } \\
\text { Salvelinus namaycush, }\end{array}$ & $\begin{array}{c}\text { The juvenile lake trout was fed with invertebrates with } \\
\text { diverse FA signatures to obtain CCs. }\end{array}$ & [22] \\
\hline Mirounga angustirostris & $\begin{array}{l}\text { The CCs were calculated from known dietary data } \\
\text { derived from an adult female elephant seal in captivity. }\end{array}$ & [19] \\
\hline Pollachius virens & $\begin{array}{c}\text { The CCs were obtained by feeding } P \text {. virens on three } \\
\text { formulated dietary. }\end{array}$ & [37] \\
\hline
\end{tabular}

\subsubsection{The Selection of FA Subsets}

The second issue, as stated above, is related to the FA subset used in assessing diets. More than 70 FAs have been identified through the gas chromatography and a polar capillary column in marine lipids studies [12]. Nevertheless, due to the influences of the predator's metabolisms, only some FAs can provide useful information for dietary estimation [38]. For example, short-chain or medium-chain FAs (i.e., $<14$ carbons) could only be produced by biosynthesis. In contrast, $n-6$ or $n-3$ polyunsaturated FAs usually only come from the diet. Due to these differences in origins, some studies have explored the utility of FA subsets rather than the full FAs.

Traditionally, the dietary or extended dietary subsets of FA investigated by Iverson et al. [5] is routinely used $[10,11,13,16,30]$. The former FAs are strictly from the diet, while the latter included several FAs that can be biosynthesized by the predator or ingested from diet [5]. In general, 
the extended dietary subset performed better in the modeling exercises, likely due to the increased information provided [8]. Besides, additional criteria were also applied by some investigators [18,19,21]. For example, Magnone et al. [15] selected seven FA sets to estimate diet; Budge et al. [21] used four FA sets; Goetsch et al. [19] adopted a new FA subset, which only included FAs derive from the diet $(n=46)$ and removed three FAs (16:4n-3, 18:1n-11, 22:1n-11) that were used in other studies. In conclusion, the optimum subsets of FA may depend on the type of predators (e.g., mammal, bird, fish) and the ecosystem studied (e.g., estuarine ecosystems, fresh water, and soil ecosystem). It is a significant area for further research.

There are generally three approaches to deal with the FA subset selected [13]: the "traditional" approach is to rescale the sum of the proportions of the FA components to $1[5,13,19]$; the "un-scaled" approach maintains the original ratio of FAs in the diet unchanged; and the "augmented" method is to add an additional ratio while maintaining the original proportions of FAs in the subset to make the sum equal to 1.

Bromaghin et al. [13] used computer simulations to compare the effects of three scaling methods based upon KL [5], Aitchison [39] and Chi square [39] distance measures on the variance and bias of dietary estimation. They recommended that researchers should check the sum of the original proportions and analyze the degree of difference among preys, and then determine whether the scaling will cause deviation.

\subsubsection{The Optimization of the Statistical Model}

QFASA has been extensively used since it was proposed and some distance measurement methods have been applied in previous studies (e.g., [5,19,39,40]), such as the KL [5], Aitchison [19,39], Chi square [39] statistical distance, although the $K L$ measure originally recommended by Iverson et al. [5] has been frequently used [39].

Dietary estimation was usually carried out in two spaces. One was the prey space, which was transformed by dividing predator FA signature by CC based on Formula (1) [5]; and the other was the predator space, which was obtained by multiplying prey FA signature by CC based on Formula (1) $[18,19]$. Bromaghin et al. [41] investigated the influence of the choice of distance measures (such as $K L$ or Aitchison) and optimization spaces (i.e., prey or predator space mentioned above) on dietary estimation in the application of the QFASA model, and revealed that the choice of evaluation method may have a significant impact on dietary estimation. Additionally, Bromaghin et al. [42] developed a new algorithm that can objectively determine the bootstrap sample size to generate a pseudo-predator signature with actual attributes, thus improving the efficacy of computer modeling to evaluate the performance of the QFASA estimator. Besides, Bromaghin et al. [40] used computer modeling to study the robustness of the Aitchison and KL distance measure, kept a record of the deviations in dietary estimation, and concluded that the former was more robust in terms of CC errors while the latter was more robust to the ingestion of preys unrepresentative in the prey profiles database. Furthermore, Litmanen et al. [43] estimated the performance of several algorithms and found that some Bayesian algorithms take longer time to calculate than QFASA, recommending the use of Chi square or $K L$ statistical distance. In conclusion, the distance measure that performs the best may depend on the ecosystem being studied, and it is recommended to test multiple measures to assess differences, or evaluate the ecosystem under controlled conditions (e.g., feeding experiments).

In the application of the QFASA model, the statistical characteristics of predator dietary estimation is usually estimated through computer simulations [42], e.g., commercial software, Fortran programs [18], R package [13,19,30,32,44,45], a combination program of $\mathrm{R}$ and Fortran [6,41], and Matlab with its optimization toolbox $[14,15,17,36]$. In recent years, Bromaghin summarized a new R package named QFASAR, calculating the goodness-of-fit diagnosis, which may enhance the performance of the prey signature database $[19,44]$. 


\subsection{Research Status of QFASA}

QFASA has become a promising approach in dietary estimation since it was proposed and its applications are shown in Table 2. In recent years, Wang et al. [11] estimated the diets of threatened S. fischeri, and concluded that infertile eggs yolks can be used to evaluate the diet of breeding female $S$. fischeri for better understanding the source and timing of nutrients during reproduction; Magnone et al. [15] estimated the diet of P. orbignyanus by QFASA, determined CC and validated the model with a controlled experiment, which quantified the diet of lower vertebrates (P. orbignyanus) for the first time; Magnone et al. [14] used QFASA to generate a food web model in the aquatic environment to find out the trophic relationships among the species; Conners et al. [20] estimated two albatross species by QFASA, and adapted the QFASA model, which introduced a combination of FAs and fatty alcohols; Goetsch et al. [19] estimated the diet composition of $M$. angustirostris, and suggested that the seals mainly fed on mesopelagic fishes; Knox et al. [24] estimated the diet of A. pusillus doriferus, finding that elasmobranchs accounted for more in the diet of males than previous reports, and showed that prey composition varied among males; Happel et al. [25] used a controlled trial to test the influence of intraspecific difference in FA signatures of prey on the QFASA model, indicating that QFASA used for steelhead trout may not only be used for a specific lake, but also for other freshwater systems with alewife and round goby as the main food; Tao [26] estimated the diet composition of Channa. argus using the QFASA model, and then calculated the biomagnifcation factors (BMFs) of the alternative halogenated flame retardants (AHFRs) based upon the results.

Table 2. The application of QFASA.

\begin{tabular}{|c|c|c|c|}
\hline Species & Species Type & Research Contents & References \\
\hline $\begin{array}{c}\text { H. grypus, } \\
\text { P. groenlandica }\end{array}$ & Marine mammals & $\begin{array}{l}\text { Proposed the QFASA model, which was the } \\
\text { first time FAs has been used to quantitatively } \\
\text { estimate the diet of predators. }\end{array}$ & [5] \\
\hline H. grypus & Marine mammals & $\begin{array}{c}\text { Conducted controlled feeding experiments } \\
\text { designed to investigate some of the issues } \\
\text { relating to CC, optimization of FA sets and } \\
\text { validation of QFASA. }\end{array}$ & [8] \\
\hline E. jubatus & Marine mammals & $\begin{array}{c}\text { Captive feeding experiments were conducted } \\
\text { on juvenile female E. jubatus to estimate the } \\
\text { ability of QFASA to recognize known } \\
\text { mixed dietary. }\end{array}$ & [34] \\
\hline E. jubatus & Marine mammals & $\begin{array}{c}\text { Simulated ephemeral feeding events of } E \text {. } \\
\text { jubatus and investigated the use of QFASA to } \\
\text { evaluate diet. }\end{array}$ & [35] \\
\hline $\begin{array}{l}\text { Rissa brevirostris, } \\
\text { Rissa ridactyla, } \\
\text { U. aalge, U. lomvia }\end{array}$ & Seabirds & $\begin{array}{l}\text { Using four species of captive and wild birds to } \\
\text { verify the application of QFASA in seabird } \\
\text { dietary estimation. }\end{array}$ & [9] \\
\hline $\begin{array}{l}\text { P. vitulina } \\
\text { richardsi }\end{array}$ & Marine mammals & $\begin{array}{c}\text { Tested the QFASA model with newly weaned } P \text {. } \\
\text { vitulina richardsi, obtained species-specific CCs, } \\
\text { and compared the credibility of QFASA with } \\
\text { previous studies. }\end{array}$ & [36] \\
\hline Ursus maritirnus & Marine mammals & $\begin{array}{l}\text { Examined the internal and external factors that } \\
\text { affect the prey selection of } U \text {. maritirnus. }\end{array}$ & [16] \\
\hline $\begin{array}{c}\text { Pagophilus } \\
\text { groenlandicus, } \\
\text { Cystophora cristata }\end{array}$ & Marine mammals & $\begin{array}{l}\text { Studied the effects of demographic, time and } \\
\text { space differences on the diet of } P \text {. groenlandicus } \\
\text { and C. cristata. }\end{array}$ & [46] \\
\hline Phocarctos hookeri & Marine mammals & $\begin{array}{l}\text { Optimized the QFASA model for bycaught } P \text {. } \\
\text { hookeri by changing some parameters (such as } \\
\text { the CC subsets used in previous studies } \\
[5,17,30]) \text {; and estimated the diet of } P \text {. hookeri by } \\
\text { optimization model. }\end{array}$ & [17] \\
\hline
\end{tabular}


Table 2. Cont.

\begin{tabular}{|c|c|c|c|}
\hline Species & Species Type & Research Contents & References \\
\hline $\begin{array}{l}\text { S. fischeri, } \\
\text { P. stelleri }\end{array}$ & Seabirds & $\begin{array}{c}\text { Developed CCs to explain the lipid metabolism } \\
\text { of eider and verified the reliability of QFASA } \\
\text { through captive experiments. }\end{array}$ & [10] \\
\hline S. salar & Marine fish & $\begin{array}{l}\text { Investigated the application of QFASA to } \\
\text { S. salar. }\end{array}$ & [21] \\
\hline Ursus maritimus & Marine mammals & $\begin{array}{l}\text { Used QFASA and } \delta^{13} \mathrm{C}-\mathrm{FA} \text { to estimate the } \\
\text { variations in the diet of } U \text {. maritimus from } 1984 \\
\text { to } 2011 \text {, which reflected the massive shifts in } \\
\text { the ecosystem of East Greenland. }\end{array}$ & [47] \\
\hline P. vitulina & Marine mammals & $\begin{array}{l}\text { Used QFASA to investigate the diets of } \\
\text { P. vitulina. }\end{array}$ & [18] \\
\hline Rhincodon typus & Marine fish & $\begin{array}{l}\text { Used QFASA and stomach content analysis to } \\
\text { identify the main prey of } R \text {. typus. }\end{array}$ & [48] \\
\hline S. fischeri & Seabirds & $\begin{array}{l}\text { Examined the diversity of FA signatures } \\
\text { between fertilized and unfertilized eggs of } \\
\text { feeding female S. fischeri, developed CC for } \\
\text { individual to explain the modification of yolk } \\
\text { on FAs derived from the dietary, and verified } \\
\text { that the QFASA model could use yolk to } \\
\text { estimate the diet of maternal. }\end{array}$ & [11] \\
\hline P. orbignyanus & Marine fish & $\begin{array}{l}\text { Estimated the quantitative diet of } P \text {. } \\
\text { orbignyanus, determined } C C \text { and validated the } \\
\text { model by controlled trials. }\end{array}$ & [15] \\
\hline $\begin{array}{l}\text { P. orbignyanus } \\
\text { and other } 21 \\
\text { species }\end{array}$ & $\begin{array}{l}\text { Marine fish, } \\
\text { plankton etc. }\end{array}$ & $\begin{array}{l}\text { Used QFASA to generate a food web model in } \\
\text { the aquatic environment to find out the trophic } \\
\text { relationships among the species and compared } \\
\text { the consequences with previous researches. }\end{array}$ & [14] \\
\hline Gavia adamsii & Seabirds & $\begin{array}{l}\text { Estimated the diet of G. adamsii breeding on the } \\
\text { Arctic Coastal Plain using QFASA. }\end{array}$ & [30] \\
\hline $\begin{array}{l}\text { Salmonidae: } \\
\text { S. namaycush }\end{array}$ & Marine mammals & $\begin{array}{c}\text { Determined the time it takes to make the FA } \\
\text { signatures of the S. namaycush similar to its } \\
\text { dietary, and evaluated the difference in CC } \\
\text { among different diets. }\end{array}$ & [22] \\
\hline $\begin{array}{l}\text { S. namaycush, } \\
\text { Neogobius } \\
\text { melanostomus, } \\
\text { Perca flavescens }\end{array}$ & Marine mammals & $\begin{array}{l}\text { Established a model for estimating diet and } \\
\text { evaluated its ability in freshwater predator. }\end{array}$ & [23] \\
\hline $\begin{array}{l}\text { Phoebastria } \\
\text { nigripes, } \\
\text { Phoebastria } \\
\text { immutabilis }\end{array}$ & Seabirds & $\begin{array}{l}\text { Estimated two albatross types by QFASA, } \\
\text { and adapted the QFASA model, } \\
\text { which introduced a combination of FAs and } \\
\text { fatty alcohols. }\end{array}$ & [20] \\
\hline M. angustirostris & Marine mammals & $\begin{array}{l}\text { Proposed a new approach to optimize prey } \\
\text { library, then evaluated the diet of } M \text {. } \\
\text { angustirostris with the optimized prey library. }\end{array}$ & [19] \\
\hline $\begin{array}{l}\text { Arctocephalus } \\
\text { pusillus doriferus }\end{array}$ & Marine mammals & $\begin{array}{l}\text { Investigated the diet composition of male } A \text {. } \\
\text { pusillus doriferus, and dietary differences among } \\
\text { males and seasonal changes in diet. }\end{array}$ & [24] \\
\hline $\begin{array}{l}\text { Oncorhynchus } \\
\text { mykiss }\end{array}$ & Freshwater fish & $\begin{array}{c}\text { The effect of intraspecific difference in the FASs } \\
\text { of preys on QFASA was verified by controlled } \\
\text { captive trial. }\end{array}$ & [25] \\
\hline Channa argus & Freshwater fish & $\begin{array}{c}\text { Estimated the diet composition of C. argus } \\
\text { using QFASA model. }\end{array}$ & [26] \\
\hline P. virens & Marine fish & $\begin{array}{l}\text { Estimated the effects of diet fat concentrations } \\
\text { on assimilation patterns of FAs in P. virens. }\end{array}$ & [37] \\
\hline Ursus maritimus & Marine mammals & $\begin{array}{l}\text { Estimated the diet composition of } U \text {. maritimus } \\
\text { by QFASA. }\end{array}$ & {$[49,50]$} \\
\hline
\end{tabular}




\section{Conclusions and Suggestions}

FAs have been widely applied in qualitative research for evaluating trophic predator-prey relationships. However, QFASA is the first attempt to use FAs to quantitatively estimate the diet of predators, which provides an insight into the function and structure of dynamic ecosystems. The core of QFASA is to find the FA signatures combination of prey that is most similar to the FA signatures of predator to infer the diet of predator. One of the most important assumptions of the QFASA model is that the metabolism of the predator is already known. Currently, the effect of predators on FA metabolism and deposition is explained by CCs, which were determined previously from captive feeding trials and could be found by calculating FA levels found in the predator over FA levels in the food. Additionally, CCs have already been evaluated in several species of marine mammals, seabirds and fish (Table 1). The refinement of which subsets of FAs are more effective for QFASA accuracy remains a topic of study. QFASA has been used in a variety of taxa (e.g., marine mammals, seabirds and fish) rather than being limited to high-trophic vertebrates, and presumably it will be tested in new taxa. If one predator in a given ecosystem meets all of the above requirements for using QFASA, it can be modeled.

Nevertheless, QFASA has several limitations. Firstly, since it is a non-probabilistic model, it is hard to evaluate the effects of the different uncertainties related with dietary proportion estimation. The handling of confidence interval in QFASA can be found in Stewart et al. [51,52]. Ecological mechanisms cannot be built directly into the model owing to the absence of an explicit model [53]. Secondly, some species are not suitable for captive experiments; therefore, accurate CCs cannot be obtained. Thirdly, the model is not applicable to all species, because some taxa lack specific fat storage organs. In addition, some factors may cause bias when QFASA is applied to fish and invertebrates, since FAs may be modified during metabolism and transportation. Some invertebrates tend to have greater ability to biosynthesize and modify the FA than higher trophic organisms, and fish have a stronger ability to modify some exogenous FAs than mammals and birds [7]; many studies have indicated that FAs with a high proportion in the diets of fish are easily catabolized [21]; the growth and reproductive stage (e.g., the proportions of 20:5n-3 and 22:6n-3 in fish eggs seems to be fixed) may affect FA signature of tissues [21]; some freshwater taxa (e.g., Daphnia) can elongate and desaturate 18:3n-3 to 20:5n-3 [7].

Several techniques have been used to study predator-prey relationships, such as stomach content analysis, IS analysis and FA analysis [54]. Traditional stomach content analysis can directly reflect the diet composition of predator, but it usually only represents a snapshot of diet and tends to underestimate the proportion of soft-bodied prey [55]. Chemical markers such as SI and FAs can reflect the long-term diet of predator. SI analysis plays an important role in evaluating the trophic level of predators, but the resolution is limited by the number of SI to be measured (e.g., typically only 2-3 SI are measured) [56]. FAs seem to provide more information than SI, because many potential FAs can be measured. However, the proportion of the measured FAs is always limited to a sum of one. Therefore, some studies have developed mixed models that combine SI and FAs, such as the Bayesian fatty acid-based mixing model (Fatty Acid Source Tracking Algorithm in R, FASTAR) [57,58] intended for zooplankton and benthic macro-invertebrates, a mixed model combining FAs with SI (FastinR), which could improve the dietary estimation with the available fat content and conversion coefficients [53], and the Bayesian mixing model framework (mixSIAR) [59], which evaluates the relative contribution of food sources in the diet of predator. As a promising method in quantitative ecosystem, QFASA relies on the distance measurement rather than model-based formulation to evaluate the most likely diet proportions, which is contrary to (Bayesian) SI and FA mixing models.

As for the future studies of QFASA, firstly, it is suggested to use QFASA in combination with other approaches (such as the SI analysis [8] or stomach content analysis [16]) to obtain more comprehensive information. Secondly, some simplification procedures of FAs extraction are expected to widen the use of the QFASA model in marine ecology and biology, such as the simplified method to extract polyunsaturated FAs [60]. Thirdly, the application of QFASA in invertebrates and low-trophic vertebrates needs further study. More studies are expected to use the QFASA model to build food 
webs [14,61]. For instance, Magnone et al. [14] generated a food web model in the aquatic environment to find out the trophic relationships among the species by QFASA. Further, captive feeding trials may provide a good way of testing if QFASA will work and its intricacies, but the predator signature produced through trials may not relate to wild species of different age, size, or lipid status even if they are fed the same prey in the wild. There is still much remaining to be known and tested with how FAs can be used in quantitative models. For instance, Goetz et al. [62] indicated that within the lake trout species different ectomorphs accumulate lipids in different ways which may mean finding CCs for plastic species may be difficult and suggests that over time CCs would need to be updated as genetics drift.

In conclusion, it has been clearly shown that FA has become an important trophic tracer in the research of carbon transfer, predator-prey relationships, food webs, along with the function and structure of dynamic ecosystem. Although QFASA has some limitations, it is still the promising approach because of its several potential advantages [12]. QFASA reflects the long-term (a period of weeks to months) diet compared with the stomach content analysis, allows more than three prey types to be estimated, and can avoid the problem of underdetermined systems common in analysis with SI markers. Results of QFASA may be useful in studies into the effects of maternal diets on offspring or the assessment of nutrient deficiencies in marine organisms [63,64].

Author Contributions: Conceptualization, J.Z.; methodology, J.Z. and C.R.; data analysis, C.R., H.Z., F.Y. and S.Z.; resources, H.Z. and S.Z.; writing-original draft preparation, J.Z. and C.R.; writing-review and editing, J.Z., C.R. and D.K.; supervision, R.W. and D.K. All authors have read and agreed to the published version of the manuscript.

Funding: This study is partly supported by the National Key Research and Development Program of China (No. 2019YFC0312104), the Young Orient Scholars Program of Shanghai (No. QD2017038), and the National Natural Science Foundation of China (No. 41807341).

Acknowledgments: The authors would like to thank Yang Chenxing for discussing the English grammar of the manuscript.

Conflicts of Interest: The authors declare no conflict of interest. The funders had no role in the design of the study; in the collection, analyses, or interpretation of data; in the writing of the manuscript, or in the decision to publish the results.

\section{References}

1. Kelly, J.R.; Scheibling, R.E. Fatty acids as dietary tracers in benthic food webs. Mar. Ecol. Prog. Ser. 2012, 446, 1-22. [CrossRef]

2. Scott, T. Some further observations on the food of fishes, with a note on the food observed in the stomach of a common porpoise. Annu. Rep. Fish. Board Scotl. Sci. Investig. 1903, 21, 218-227.

3. Fry, B.; Sherr, E.B. $813 \mathrm{C}$ measurements as indicators of carbon flow in marine and freshwater ecosystems. In Stable Isotopes in Ecological Research, 2nd ed.; Springer: New York, NY, USA, 1989; pp. 196-229.

4. Sargent, J.R.; Falkpetersen, S. The lipid biochemistry of calanoid copepods. Hydrobiologia 1988, 167, 101-114. [CrossRef]

5. Iverson, S.J.; Field, C.; Bowen, W.D.; Blanchard, W. Quantitative fatty acid signature analysis: A new method of estimating predator diets. Ecol. Monogr. 2004, 74, 211-235. [CrossRef]

6. Olsen, Y. Lipids and essential fatty acids in aquatic food webs: What can freshwater ecologists learn from mariculture. In Lipids in Freshwater Ecosystems, 2nd ed.; Springer: New York, NY, USA, 1999; Volume 8, pp. 161-202.

7. Iverson, S.J. Tracing aquatic food webs using fatty acids: From qualitative indicators to quantitative determination. In Lipids in Aquatic Ecosystems, 2nd ed.; Springer: New York, NY, USA, 2009; Volume 12, pp. 281-308.

8. Cooper, M.H. Fatty Acid Metabolism in Marine Carnivores: Implications for Quantitative Estimation of Predator Diets. Ph.D. Thesis, Dalhousie University, Halifax, NS, Canada, 2004.

9. Iverson, S.J.; Springer, A.M.; Kitaysky, A.S. Seabirds as indicators of food web structure and ecosystem variability: Qualitative and quantitative diet analyses using fatty acids. Mar. Ecol. Prog. Ser. 2007, 352, 235-244. [CrossRef] 
10. Wang, S.W.; Hollmén, T.E.; Iverson, S.J. Validating quantitative fatty acid signature analysis to estimate diets of spectacled and Steller's eiders (Somateria fischeri and Polysticta stelleri). J. Comp. Physiol. B Biochem. Syst. Environ. Physiol. 2010, 180, 125-139. [CrossRef]

11. Wang, S.W.; Hollmén, T.E.; Iverson, S.J. Egg yolk fatty acids as a proxy to quantify diets of female spectacled eiders (Somateria fischeri). Can. J. Zool. 2014, 92, 453-461. [CrossRef]

12. Budge, S.M.; Iverson, S.J.; Koopman, H.N. Studying trophic ecology in marine ecosystems using fatty acids: A primer on analysis and interpretation. Mar. Mammal Sci. 2006, 22, 759-801. [CrossRef]

13. Bromaghin, J.F.; Budge, S.M.; Thiemann, G.W. Should fatty acid signature proportions sum to 1 for diet estimation? Ecol. Res. 2016, 31, 597-606. [CrossRef]

14. Magnone, L.; Bessonart, M.; Gadea, J.; Salhi, M. Trophic relationships in an estuarine environment: A quantitative fatty acid analysis signature approach. Estuar. Coast. Shelf Sci. 2015, 166, 24-33. [CrossRef]

15. Magnone, L.; Bessonart, M.; Rocamora, M.; Gadea, J.; Salhi, M. Diet estimation of Paralichthys orbignyanus in a coastal lagoon via quantitative fatty acid signature analysis. J. Exp. Mar. Biol. Ecol. 2015, 462, 36-49. [CrossRef]

16. Thiemann, G.W.; Iverson, S.J.; Stirling, I. Polar bear diets and arctic marine food webs: Insights from fatty acid analysis. Ecol. Monogr. 2008, 78, 591-613. [CrossRef]

17. Meynier, L.; Morel, P.C.H.; Chilvers, B.L.; Mackenzie, D.D.S.; Duignan, P.J. Quantitative fatty acid signature analysis on New Zealand sea lions: Model sensitivity and diet estimates. J. Mammal 2010, 91, 1484-1495. [CrossRef]

18. Bromaghin, J.F.; Lance, M.M.; Elliott, E.W.; Jeffries, S.J.; Acevedo-Gutiérrez, A.; Kennish, J.M. New insights into the diets of harbor seals (Phoca vitulina) in the Salish Sea revealed by analysis of fatty acid signatures. Fish. Bull. 2013, 111, 13-26. [CrossRef]

19. Goetsch, C.; Conners, M.G.; Budge, S.M.; Mitani, Y.; Walker, W.A.; Bromaghin, J.F. Energy-Rich mesopelagic fishes revealed as a critical prey resource for a deep-diving predator using quantitative fatty acid signature analysis. Front. Mar. Sci. 2018, 5, 1-19. [CrossRef]

20. Conners, M.G.; Chandra, G.; Budge, S.M.; Walker, W.A.; Yoko, M.; Costa, D.P. Fisheries Exploitation by Albatross Quantified With Lipid Analysis. Front. Mar. Sci. 2018, 5, 1-17. [CrossRef]

21. Budge, S.M.; Penney, S.N.; Lall, S.P.; Trudel, M. Estimating diets of Atlantic salmon (Salmo salar) using fatty acid signature analyses; validation with controlled feeding studies. Can. J. Fish. Aquat. Sci. 2012, 69, 1033-1046. [CrossRef]

22. Happel, A.; Stratton, L.; Kolb, C.; Hays, C.; Rinchard, J.; Czesny, S. Evaluating quantitative fatty acid signature analysis (QFASA) in fish using controlled feeding experiments. Can. J. Fish. Aquat. Sci. 2016, 73, 1222-1229. [CrossRef]

23. Happel, A.; Stratton, L.; Pattridge, R.; Rinchard, J.; Czesny, S. Fatty-acid profiles of juvenile lake trout reflect experimental diets consisting of natural prey. Freshw. Biol. 2016, 61, 1466-1476. [CrossRef]

24. Knox, T.C.; Callahan, D.L.; Kernaléguen, L.; Baylis, A.M.M.; Arnould, J.P.Y. Blubber fatty acids reveal variation in the diet of male Australian fur seals. Mar. Biol. 2019, 166, 117. [CrossRef]

25. Happel, A.; Maier, C.; Farese, N.V.; Czesny, S.; Rinchard, J. Fatty acids differentiate consumers despite variation within prey fatty acid profiles. Freshw. Biol. 2019, 64, 1416-1426. [CrossRef]

26. Tao, L. Bioaccumulation Characteristics and Trophic Magnification of Alternative Halogenated Flame Retardants. Ph.D. Thesis, University of Chinese Academy of Sciences (Guangzhou Institute of Geochemistry Chinese Academy of Sciences), Guangzhou, China, 2019.

27. Keinänen, M.; Käkelä, R.; Ritvanen, T.; Pönni, J.; Harjunpää, H.; Myllylä, T.; Vuorinen, P.J. Fatty acid signatures connect thiamine deficiency with the diet of the Atlantic salmon (Salmo salar) feeding in the Baltic Sea. Mar. Biol. 2018, 165, 161. [CrossRef] [PubMed]

28. Phillips, D.L.; Inger, R.; Bearhop, S.; Jackson, A.L.; Moore, J.W.; Parnell, A.C. Best practices for use of stable isotope mixing models in food-web studies. Can. J. Zool. 2014, 92, 823-835. [CrossRef]

29. Piché, J.; Iverson, S.J.; Parrish, F.A.; Dollar, R. Characterization of forage fish and invertebrates in the Northwestern Hawaiian Islands using fatty acid signatures: Species and ecological groups. Mar. Ecol. Prog. Ser. 2010, 418, 1-15. [CrossRef]

30. Haynes, T.B.; Schmut, J.A.; Bromaghin, J.F.; Iverson, S.J.; Padula, V.M.; Rosenberger, A.E. Diet of yellow-billed loons (Gavia adamsii) in Arctic lakes during the nesting season inferred from fatty acid analysis. Polar Biol. 2015, 38, 1239-1247. [CrossRef] 
31. Tollit, D.J.; Rosen, D.A.S.; Iverson, S.J.; Trites, A.W. Stellar sea lion QFASA captive feeding studies. National Oceanic and Atmospheric Administration. Final Rep. North Pac. Univ. Mar. Mammal Res. Consort. 2007, 9, 1-35.

32. Rosen, D.; Tollit, D. Effects of phylogeny and prey type on fatty acid calibration coefficients in three pinniped species: Implications for the QFASA dietary quantification technique. Mar. Ecol. Prog. 2012, 467, 263-276. [CrossRef]

33. Bromaghin, J.F.; Budge, S.M.; Thiemann, G.W.; Rode, K.D. Simultaneous estimation of diet composition and calibration coefficients with fatty acid signature data. Ecol. Evol. 2017, 7, 6103-6113. [CrossRef]

34. Tollit, D.J.; Heaslip, S.G.; Deagle, B.E.; Iverson, S.I.; Joy, R.; Rosen, D.A.S.; Trites, A.W. Estimating diet composition in sea lions: Which technique to choose. In Sea Lions of the World; Trites, A.W., Atkinson, S.K., DeMaster, D.P., Fritz, L.W., Gelatt, T.S., Rea, L.D., Wynne, K.M., Eds.; Alaska Sea Grant College Program, University of Alaska Fairbanks: Fairbanks, AL, USA, 2006; pp. 293-308.

35. Hoberecht, L.K. Investigating the Use of Blubber Fatty Acids to Detect Steller Sealion (Eumetopias jubatus) Foraging on Ephemeral High-Quality Prey. Ph.D. Thesis, University of Washington, Seattle, WA, USA, 2006.

36. Nordstrom, C.A.; Wilson, L.J.; Iverson, S.J.; Tollit, D.J. Evaluating quantitative fatty acid signature analysis (QFASA) using harbour seals Phoca vitulina richardsi in captive feeding studies. Mar. Ecol. Prog. Ser. 2008, 360, 245-263. [CrossRef]

37. Budge, S.M.; Townsend, K.; Lall, S.P.; Bromaghin, J.F. Dietary fat concentrations influence fatty acid assimilation patterns in Atlantic pollock (Pollachius virens). Philos. Trans. R. Soc. B 2020, 375, 20190649. [CrossRef]

38. Iverson, S.J.; Bowen, W.D.; Boness, D.J.; Oftedal, O.T. The effect of maternal size and milk energy output on pup growth in grey seals (Halichoerus grypus). Physiol. Biochem. Zool. 1993, 66, 61-88. [CrossRef]

39. Stewart, C.; Iverson, S.J.; Field, C. Testing for a change in diet using fatty acid signatures. Environ. Ecol. Stat. 2014, 21, 775-792. [CrossRef]

40. Bromaghin, J.F.; Budge, S.M.; Thiemann, G.W.; Rode, K.D. Assessing the robustness of quantitative fatty acid signature analysis to assumption violations. Methods Ecol. Evol. 2016, 7, 51-59. [CrossRef]

41. Bromaghin, J.F.; Rode, K.D.; Budge, S.M.; Thiemann, G.W. Distance measures and optimization spaces in quantitative fatty acid signature analysis. Ecol. Evol. 2015, 5, 1249-1262. [CrossRef] [PubMed]

42. Bromaghin, J.F. Simulating realistic predator signatures in quantitative fatty acid signature analysis. Ecol. Inform. 2015, 30, 68-71. [CrossRef]

43. Litmanen, J.J.; Perälä, T.A.; Taipale, S.J. Comparison of Bayesian and numerical optimization-based diet estimation on herbivorous zooplankton. Philos. Trans. R. Soc. B 2020, 375, 20190651. [CrossRef] [PubMed]

44. Bromaghin, J.F. QFASAR: Quantitative fatty acid signature analysis with R. Methods Ecol. Evol. 2017, 8, 1158-1162. [CrossRef]

45. Bromaghin, J.F.; Budge, S.M.; Thiemann, G.W. Detect and exploit hidden structure in fatty acid signature data. Ecosphere 2017, 8, 1-13. [CrossRef]

46. Tucker, S.; Bowen, W.D.; Iverson, S.J.; Blanchard, W.; Stenson, G.B. Sources of variation in diets of harp and hooded seals estimated from quantitative fatty acid signature analysis (QFASA). Mar. Ecol. Prog. Ser. 2009, 384, 287-302. [CrossRef]

47. Mckinney, M.A.; Iverson, S.J.; Fisk, A.T.; Sonne, C.; Rigét, F.F.; Letcher, R.J. Global change effects on the long-term feeding ecology and contaminant exposures of East Greenland polar bears. Glob. Chang. Biol. 2013, 19, 2360-2372. [CrossRef]

48. Rohner, C.A.; Couturier, L.I.E.; Richardson, A.J.; Pierce, S.J.; Prebble, C.E.M.; Gibbons, M.J.; Nichols, P.D. Diet of whale sharks Rhincodon typus inferred from stomach content and signature fatty acid analyses. Mar. Ecol. Prog. Ser. 2013, 493, 219-235. [CrossRef]

49. Bourque, J.; Atwood, T.C.; Divoky, G.J.; Stewart, C.; McKinney, M.A. Fatty acid-based diet estimates suggest ringed seal remain the main prey of southern Beaufort Sea polar bears despite recent use of onshore food resources. Ecol. Evol. 2020, 10, 2093-2103. [CrossRef] [PubMed]

50. Florko, K.R.N.; Thiemann, G.W.; Bromaghin, J.F. Drivers and consequences of apex predator diet composition in the Canadian Beaufort Sea. Oecologia 2020, 19, 51-63. [CrossRef]

51. Stewart, C.; Field, C. Managing the essential zeros in quantitative fatty acid signature analysis. J. Agric. Biol. Environ. Stat. 2011, 16, 45-69. [CrossRef] 
52. Stewart, C. Zero-inflated beta distribution for modeling the proportions in quantitative fatty acid signature analysis. J. Appl. Stat. 2013, 40, 985-992. [CrossRef]

53. Neubauer, P.; Jensen, O.P. Bayesian estimation of predator diet composition from fatty acids and stable isotopes. PeerJ 2015, 3, 1-19. [CrossRef] [PubMed]

54. Bowen, W.D.; Iverson, S.J. Methods of estimating marine mammal diets: A review of validation experiments and sources of bias and uncertainty. Mar. Mammal Sci. 2013, 29, 719-754. [CrossRef]

55. Brush, J.M.; Fisk, A.T.; Hussey, N.E.; Johnson, T.B. Spatial and seasonal variability in the diet of round goby (Neogobius melanostomus): Stable isotopes indicate that stomach contents overestimate the importance of dreissenids. Can. J. Fish. Aquat. Sci. 2012, 69, 573-586. [CrossRef]

56. Phillips, D.L. Mixing models in analyses of diet using multiple stable isotopes: A critique. Oecologia 2001, 127, 166-170. [CrossRef]

57. Galloway, A.W.E.; Eisenlord, M.E.; Dethier, M.N.; Holtgrieve, G.; Brett, M.T. Quantitative estimates of resource utilization by an herbivorous isopod using a Bayesian fatty acid mixing model. Mar. Ecol. Prog. Ser. 2014, 507, 219-232. [CrossRef]

58. Galloway, A.W.E.; Taipale, S.J.; Hiltunen, M.; Peltomaa, E.; Strandberg, U.; Brett, M.T.; Kankaala, P. Diet specific biomarkers show that high quality phytoplankton fuel herbivorous zooplankton in large boreal lakes. Freshw. Biol. 2014, 59, 1902-1915. [CrossRef]

59. Jankowska, E.; Troch, M.D.; Michel, L.N.; Lepoint, G.; Wodarska-Kowalczuk, M. Modification of benthic food web structure by recovering seagrass meadows, as revealed by trophic markers and mixing models. Ecol. Indic. 2018, 90, 28-37. [CrossRef]

60. Kang, J.X.; Wang, J.A. Simplified method for analysis of polyunsaturated fatty acids. BMC Biochem. 2005, 6, 5. [CrossRef] [PubMed]

61. Kühn, J.; Tobias, K.; Jähngen, A.; Ruess, L. Shifting systems: Prerequisites for the application of quantitative fatty acid signature analysis in soil food webs. Philos. Trans. R. Soc. B 2020, 375, 20190650.

62. Goetz, F.; Jasonowicz, A.; Johnson, R.; Biga, P.; Fischer, G.; Sitar, S. Physiological differences between lean and siscowet lake trout morphotypes: Are these metabolotypes? Can. J. Fish. Aquat. Sci. 2014, 71, 427-435. [CrossRef]

63. Ballester-Lozano, G.F.; Benedito-Palos, L.; Estensoro, I.; Sitjà-Bobadilla, A.; Kaushik, S.; Pérez-Sánchez, J. Comprehensive biometric, biochemical and histopathological assessment of nutrient deficiencies in gilthead sea bream fed semi-purified diets. Br. J. Nutr. 2015, 114, 713-726. [CrossRef]

64. Kyneb, A.; Toft, S. Effects of maternal diet quality on offspring performance in the rove beetle tachyporus hypnorum. Ecol. Entomol. 2006, 31, 322-330. [CrossRef]

Publisher's Note: MDPI stays neutral with regard to jurisdictional claims in published maps and institutional affiliations.

(C) 2020 by the authors. Licensee MDPI, Basel, Switzerland. This article is an open access article distributed under the terms and conditions of the Creative Commons Attribution (CC BY) license (http://creativecommons.org/licenses/by/4.0/). 